\title{
A Scoping Review of Life-Course Psychosocial Stress and Kidney Function
}

\author{
Jesus Alejandro Estevez-Garcia ${ }^{1}$, Marcela Tamayo-Ortiz ${ }^{2, *}$ and Alison P. Sanders ${ }^{3}$ \\ 1 Centre for Population Health Research, Environmental Health Department, National Institute of Public \\ Health (INSP), Cuernavaca 62100, Mexico; jesus.estevez@espm.insp.mx \\ 2 Occupational Health Research Unit, Instituto Mexicano del Seguro Social, Mexico City 06720, Mexico \\ 3 Department of Environmental and Occupational Health, University of Pittsburgh, Pittsburgh, PA 15260, USA; \\ APS109@pitt.edu \\ * Correspondence: marcela.tamayo@imss.gob.mx
}

Citation: Estevez-Garcia, J.A.; Tamayo-Ortiz, M.; Sanders, A.P. A Scoping Review of Life-Course Psychosocial Stress and Kidney Function. Children 2021, 8, 810 . https://doi.org/10.3390/ children 8090810

Academic Editor: Pierluigi Marzuillo

Received: 2 August 2021

Accepted: 8 September 2021

Published: 16 September 2021

Publisher's Note: MDPI stays neutral with regard to jurisdictional claims in published maps and institutional affiliations.

Copyright: (c) 2021 by the authors. Licensee MDPI, Basel, Switzerland. This article is an open access article distributed under the terms and conditions of the Creative Commons Attribution (CC BY) license (https:// creativecommons.org/licenses/by/ $4.0 /)$.

\begin{abstract}
Increased exposure to maternal psychosocial stress during gestation and adverse neonatal environments has been linked to alterations in developmental programming and health consequences in offspring. A programmed low nephron endowment, among other altered pathways of susceptibility, likely increases the vulnerability to develop chronic kidney disease in later life. Our aim in this scoping review was to identify gaps in the literature by focusing on understanding the association between life-course exposure to psychosocial stress, and the risk of reduced kidney function. A systematic search in four databases (PubMed, ProQuest, Wed of Science, and Scopus) was performed, yielding 609 articles. Following abstract and full-text review, we identified 19 articles meeting our inclusion criteria, reporting associations between different psychosocial stressors and an increase in the prevalence of kidney disease or decline in kidney function, mainly in adulthood. There are a lack of studies that specifically evaluated the association between gestational exposure to psychosocial stress and measures of kidney function or disease in early life, despite the overall evidence consistent with the independent effects of prenatal stress on other perinatal and postnatal outcomes. Further research will establish epidemiological studies with clear and more comparable psychosocial stressors to solve this critical research gap.
\end{abstract}

Keywords: psychosocial stress; early-life exposure; adverse life events; nephron endowment; kidney development

\section{Introduction}

Kidney disease is a rapidly growing global health problem, both as a direct cause of morbidity and mortality as well as an important risk factor for cardiovascular disease [1,2]. The global all-age mortality rate from chronic kidney disease (CKD) increased 41.5\% (95\% Confidence Interval (CI): 35.2, 46.5) between 1990 and 2017. The global prevalence of CKD in 2017 was $9.1 \%(95 \%$ CI: 8.5, 9.8) after controlling for two primary comorbidities affecting kidney function: hypertension and diabetes. These trends indicate that CKD represents a serious threat to global public health and the economy [1,2]. Therefore, identifying preventable risk factors is essential for reducing CKD burden [3].

Stress-related psychosocial factors have repeatedly been associated with different non-communicable diseases, with studies linking stress to poorer kidney function $[4,5]$, and prenatally, psychosocial stressors have been associated with adverse perinatal outcomes, including low birth weight, small for gestational age, and preterm birth [6,7]. However, the contribution of psychosocial stress to kidney development and diseases [8,9] has remained relatively unexplored.

The Developmental Origins of Health and Disease (DOHaD) hypothesis [10] postulates that adverse exposures during pregnancy or long before conception can result in poor fetal growth and impair normal development and organogenesis [6,11]. Nephrogenesis, 
the process of new nephron formation in the kidney, has been shown to be impacted by different harmful early-life exposures, including an inadequate diet, poor placental function, maternal stress, maternal smoking, and alcohol consumption, reducing the renal functional capacity (endowment) established at birth, which enhances an individual's susceptibility to CKD and hypertension in later life [12-14]. There is an inverse correlation between the total number of nephrons and the risk of developing CKD and hypertension [13].

The purpose of this work is to provide an overview of the existing literature on exposure to psychosocial stress and effects on kidney function to advance conceptual clarity, synthesize the literature, and identify priorities for future research with a particular emphasis on early life exposures.

\section{Materials and Methods}

We followed the methodology by Arksey and O'Malley [15] and reported according to the guidelines for scoping reviews (PRISMA-ScR) [16].

The research question was: "What is the contribution between exposure to psychosocial stress and kidney development and diseases?". Search strategy results are defined in Table 1. The search was conducted during June 2021, spanning literature published between January 2000 and May 2021, using PubMed (MEDLINE), ProQuest Central, Web of Science, and Scopus. Manual searches of reference lists of systematic and other literature reviews identified additional primary studies. Literature was included if it primarily addressed (1) kidney function or diseases, (2) psychosocial stressors exposure in early or adult life (>18 years), (3) birth cohorts or longitudinal studies, or (4) experimental studies, in English.

Table 1. Search strategy, terms, and results for traditional databases.

\begin{tabular}{|c|c|c|c|c|c|}
\hline \multirow[t]{2}{*}{ Step } & \multirow[t]{2}{*}{ Search Description } & \multicolumn{4}{|c|}{ Results } \\
\hline & & PUBMED & SCOPUS & ProQuest & Web of Science \\
\hline 1 & 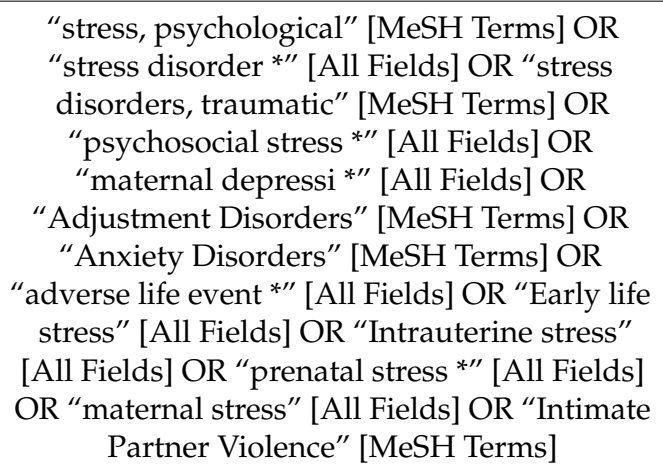 & 282,346 & 305,521 & 637,299 & 384,716 \\
\hline 2 & $\begin{array}{l}1 \text { AND “kidney function tests" [MeSH Terms] } \\
\text { OR “kidney function" [Text Word] OR "renal } \\
\text { function" [Text Word] OR “Acute Kidney } \\
\text { Injury" [MeSH Terms] OR “kidney failure, } \\
\text { chronic" [MeSH Terms] OR “Glomerular } \\
\text { Filtration Rate" [MeSH Terms] OR "renal } \\
\text { function decline" [Text Word] }\end{array}$ & 522 & 723 & 3895 & 3900 \\
\hline 3 & $\begin{array}{l}2 \text { AND (“birth cohort*"[Text Word] OR } \\
\text { "Longitudinal Studies"[MeSH Terms] OR } \\
\text { "Cohort Studies"[MeSH Terms]) }\end{array}$ & 57 & 44 & 209 & 299 \\
\hline Total & & & & 609 & \\
\hline $\begin{array}{l}\text { Excluding } \\
\text { duplicates }\end{array}$ & & & & 26 & \\
\hline
\end{tabular}


We defined 'psychosocial stressor' as a life situation that creates an unusual or intense level of stress that may contribute to the development or aggravation of mental disorder, illness, or maladaptive behavior (i.e., divorce, the death of a child, prolonged illness, unwanted change of residence, a natural catastrophe, or a highly competitive work situation), in accordance with the American Psychological Association definition [17]. In addition, other psychosocial stressors were included according to the diagnostic and statistical manual of mental disorders DSM-IV-TR Axis IV in nine groups: problems with primary support groups, problems related to the social environment, educational problems, occupational problems, housing problems, economic problems, problems with access to health care, problems related to interactions with the legal system/crime legal charges, other psychosocial and environmental problems [18].

We excluded studies where the study population consisted of subjects with noncommunicable disease (diabetes mellitus, hypertension, obesity or cancer) history. Additionally, conference abstracts, letter, notes, and comments were excluded.

The PRISMA flow diagram depicting the article selection process is shown in Figure 1. Initial exclusions were made independently by J.A.E.-G and M.T.-O. based on title and abstract (Eligibility Step 1). J.A.E.-G reviewed full-text articles for eligibility and conferred with authors M.T.-O. and A.P.S. in cases of ambiguity (Eligibility Step 2).

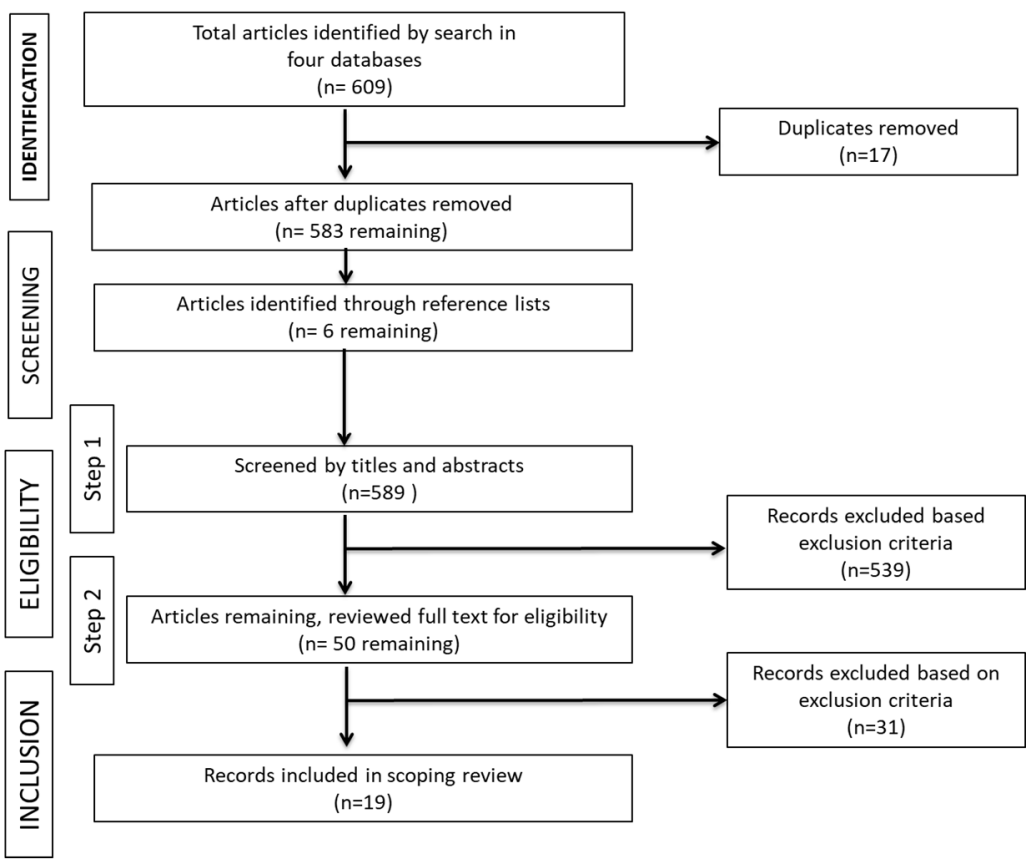

Figure 1. PRISMA flow diagram depicting the article selection process.

Data were extracted using a predesigned form and included the year of publication, author, study design, country, population and settings, outcomes studied, primary results and conclusions.

\section{Results}

A total of 19 articles were identified an included in this review. Our main finding was the lack of human studies focusing on gestational exposure to psychosocial stress; this was mostly assessed in animal studies. The majority of epidemiologic studies examined adult psychosocial stressors (most often assessed by socio economic status (SES)) and reported inverse relationships with CKD status or kidney function, but this was not consistent across all studies: there were significant associations between low socioeconomic status with CKD, especially among women and African Americans [19-23]. Adjei et al. reported associations between stress at work/home and increased albuminuria and CKD risk [24]. Other psychosocial stress such as goal-striving stress (GSS) and stress-related 
disorders were associated with rapid kidney function decline (RKFD) after adjusting for demographics, health behaviors, risk factors, and the burden of discrimination $[3,25,26]$. In contrast, higher optimism was associated with lower odds of CKD and lower odds of RKFD [27].

\subsection{Study Designs and General Characteristics}

Articles included $n=2$ cross-sectional studies [19,24], $n=1$ retrospective cohort [20], $n=8$ prospective cohort studies [3,19,21-23,25-28] and $n=8$ animal model studies [29-36]. The epidemiological studies included data for adults with different age distributions, ethnic compositions and who lived in both urban and rural areas. Seven of the studies were carried out in the United States (Jackson Heart Study, Healthy Aging in Neighborhoods of Diversity across the Life Span HANDLS study, Life Course Socioeconomic Status Study), one in Korea (KoGES study), Sweden (SCREAM project), and Ghana-Netherlands-GermanyUnited Kingdom (Research on Obesity \& Diabetes among African Migrants RODAM study). Table 2 summarizes the results of these studies, starting with epidemiological studies followed by experimental studies.

Table 2. Findings from the included articles reporting the association between psychosocial stressors and kidney outcomes in experimental and epidemiological studies.

\begin{tabular}{|c|c|c|c|}
\hline \multicolumn{4}{|c|}{ Epidemiological Studies } \\
\hline Population & Exposure & Outcome & Key Findings \\
\hline \multicolumn{4}{|c|}{ 1. Shoham et al., 2007} \\
\hline $\begin{array}{l}n=12,631 \text { adults Life } \\
\text { Course Socioeconomic } \\
\text { Status (LCSES) } \\
\text { ancillary study } \\
\text { retrospective cohort. }\end{array}$ & $\begin{array}{l}\text { Social class, education } \\
\text { level, or area-level } \\
\text { socioeconomic resources } \\
\text { in childhood and } \\
\text { adulthood }\end{array}$ & $\begin{array}{l}\text { Increased risk of adult } \\
\text { kidney disease. }\end{array}$ & $\begin{array}{c}\text { Socioeconomic factors, including area } \\
\text { socioeconomic status and social class were } \\
\text { associated with CKD and may account for some } \\
\text { observed racial disparities }\end{array}$ \\
\hline \multicolumn{4}{|c|}{ 2. Bruce et al., 2010} \\
\hline $\begin{array}{l}n=5301 \\
\text { Jackson Heart Study } \\
\text { (JHS) prospective } \\
\text { cohort. }\end{array}$ & $\begin{array}{l}\text { Socioeconomic status } \\
\text { (SES) }\end{array}$ & $\begin{array}{l}\text { Chronic kidney } \\
\text { disease }(\mathrm{CKD})\end{array}$ & $\begin{array}{l}\text { High SES was associated with lower risks for CKD, } \\
\text { although the results were not linear. }\end{array}$ \\
\hline \multicolumn{4}{|c|}{ 3. Crews et al., 2010} \\
\hline $\begin{array}{l}\quad n=2375 \\
\text { Healthy Aging in } \\
\text { Neighborhoods of } \\
\text { Diversity Across the } \\
\text { Lifespan (HANDLS) } \\
\text { Study }\end{array}$ & $\begin{array}{l}\text { Individual-level SES, } \\
\text { race }\end{array}$ & $\begin{array}{l}\text { Chronic kidney } \\
\text { disease (CKD) }\end{array}$ & $\begin{array}{c}\text { Individual-level poverty (low SES) was associated } \\
\text { with prevalent CKD among African Americans, } \\
\text { but not among whites } \\
\text { Among African Americans, low SES was } \\
\text { independently associated with a nearly twofold } \\
\text { greater risk of CKD when compared with higher } \\
\text { SES }\end{array}$ \\
\hline \multicolumn{4}{|c|}{ 4. Beydoun et al., 2017} \\
\hline $\begin{array}{l}n=1620 \\
\text { HANDLS }\end{array}$ & $\begin{array}{l}\text { Self-reported perceived } \\
\text { racial discrimination, } \\
\text { perceived gender } \\
\text { discrimination }\end{array}$ & $\begin{array}{l}\text { Chronic kidney } \\
\text { disease }(\mathrm{CKD})\end{array}$ & $\begin{array}{l}\text { Poor kidney function assessed by glomerular } \\
\text { filtration rate } \\
\text { The strength of associations differed by sex and } \\
\text { race groups }\end{array}$ \\
\hline \multicolumn{4}{|c|}{ 5. Lunyera et al., 2018} \\
\hline $\begin{array}{l}n=5301 \\
\text { JHS }\end{array}$ & $\begin{array}{l}\text { Non-depressive } \\
\text { psychosocial factors }\end{array}$ & $\begin{array}{l}\text { Chronic kidney } \\
\text { disease }(\mathrm{CKD})\end{array}$ & $\begin{array}{l}\text { Life stressors were inversely associated with } \\
\text { prevalent CKD at baseline. } \\
\text { No other associations between psychosocial } \\
\text { factors and CKD outcomes were evident after a } \\
\text { median follow-up of } 8 \text { years. }\end{array}$ \\
\hline
\end{tabular}


Table 2. Cont.

\begin{tabular}{|c|c|c|c|}
\hline \multicolumn{4}{|c|}{ Epidemiological Studies } \\
\hline Population & Exposure & Outcome & Key Findings \\
\hline \multicolumn{4}{|c|}{ 6. Adjei DN et al., 2019} \\
\hline $\begin{array}{c}\qquad n=5659 \\
\text { Research on Obesity \& } \\
\text { Diabetes among } \\
\text { African Migrants } \\
\text { (RODAM) multicenter } \\
\text { cross-sectional study }\end{array}$ & $\begin{array}{l}\text { Psychosocial stressors } \\
\text { (discrimination, } \\
\text { perceived stress at work } \\
\text { or at home, negative life } \\
\text { events and depressive } \\
\text { symptoms) }\end{array}$ & $\begin{array}{l}\text { Chronic kidney } \\
\text { disease }(\mathrm{CKD})\end{array}$ & $\begin{array}{l}\text { Positive association between stress at work/home } \\
\text { and albuminuria and CKD risk. }\end{array}$ \\
\hline \multicolumn{4}{|c|}{ 7. Cain-Shields et al., 2020} \\
\hline $\begin{array}{l}n=5301 \\
\text { JHS }\end{array}$ & Goal-striving stress & $\begin{array}{l}\text { Rapid kidney function } \\
\text { decline }\end{array}$ & $\begin{array}{l}\text { Stress related to not achieving goals was associated } \\
\text { with a greater risk of rapid kidney function decline }\end{array}$ \\
\hline \multicolumn{4}{|c|}{ 8. Glover LM et al., 2020} \\
\hline $\begin{array}{l}n=5301 \\
\text { JHS }\end{array}$ & Dispositional optimism & $\begin{array}{l}\text { Chronic kidney } \\
\text { disease (CKD) } \\
\text { Rapid kidney function } \\
\text { decline }\end{array}$ & $\begin{array}{c}\text { Higher optimism was associated with lower odds } \\
\text { of CKD and lower odds of rapid kidney function } \\
\text { decline }\end{array}$ \\
\hline
\end{tabular}

9. Kim JY. et al., 2020

$n=7246$

Korean Genome and Epidemiology Study (KoGES)
Psychosocial distress

Annual glomerular filtration rate (eGFR) decline
Higher levels of psychosocial distress were closely associated with an increased risk of rapid kidney function decline

Increase in risk was independent of sociodemographic characteristics or behavioral patterns

10. Lunyera et al., 2020

$\begin{array}{cc}n=5301 & \begin{array}{c}\text { Cumulative lifetime } \\ \text { socioeconomic status } \\ \text { JHS }\end{array} \\ \text { (SES), } \\ \text { allostatic load mediation }\end{array}$

\section{Chronic kidney} disease (CKD)
Lower cumulative lifetime SES associated with baseline CKD prevalence directly and indirectly via allostatic load

Modestly associated with CKD incidence and eGFR decline via baseline allostatic load

\section{Su G et al., 2021}

$n=30,998$

Stockholm CREAtinine

Measurements-

SCREAM

project
Stress-related disorders (SRD)
Risk of chronic kidney disease (CKD) progression

Acute kidney injury (AKI)
SRDs were associated with a subsequent risk of $\mathrm{AKI}$ and CKD progression, independent of history of other psychiatric disorders, comorbidities and medications

Risk of AKI highest within the first year from SRD diagnosis, CKD risk sustained over time

\section{Experimental Studies}

$\begin{array}{ccc}\text { Population } & \text { Exposure } & \text { Outcome } \\ & \text { 1. Singh et al., } 2007\end{array}$

- Prenatal

$n=20$

Sprague Dawley rats
- Maternal natural

glucocorticoid corticosterone (CORT) treatment
Renin-angiotensin system (RAS) of the embryo and adolescent offspring.

\section{Key findings}

Nephron deficit and development of hypertension in rat offspring.

Outcomes not influenced by birth weight In the embryonic period, altered expression of receptors of RAS may have contributed to nephron deficit

In the postnatal period, it may have contributed to hypertension

Study suggests that increased physiological levels of CORT can program similar changes to those seen with pharmacological doses of the synthetic glucocorticoid 
Table 2. Cont.

\begin{tabular}{|c|c|c|c|}
\hline \multicolumn{4}{|c|}{ Epidemiological Studies } \\
\hline Population & Exposure & Outcome & Key Findings \\
\hline \multicolumn{4}{|c|}{ 2. DeSouza et al., 2011} \\
\hline $\begin{array}{c}\quad n=15 \\
\text { Wistar male rats } \\
\text { 4-week-old (prepuberal) }\end{array}$ & $\begin{array}{l}\text { - Physical } \\
\text { immobilization until } 9 \\
\text { weeks of age } \\
\quad(n=8) \\
\text { - Control group }(n=7)\end{array}$ & $\begin{array}{c}\text { Kidney morphometrical } \\
\text { analysis } \\
\text { Total number of } \\
\text { glomeruli per kidney } \\
\text { and glomerular volume } \\
\text { density. } \\
\text { Adrenal mass index, } \\
\text { creatinine, and } \\
\text { testosterone serum } \\
\text { concentration }\end{array}$ & $\begin{array}{c}\text { Chronic stress before puberty causes an } \\
\text { important reduction in the number of } \\
\text { nephrons }(36 \%) \text { in rats without raising serum } \\
\text { creatinine } \\
\text { Morphological alterations may have serious } \\
\text { implications predisposing individuals to renal } \\
\text { disease and hypertension in adult life }\end{array}$ \\
\hline \multicolumn{4}{|c|}{ 3. Loria et al., 2013} \\
\hline $\begin{array}{c}n=6-8 / \text { group } \\
\text { Wistar Kyoto rats }\end{array}$ & $\begin{array}{l}\text { Maternal separation } \\
\text { (MatSep) } \mathrm{f} \\
\text { postnatal period (days } 2 \\
\text { to } 14 \text { ) }\end{array}$ & $\begin{array}{l}\text { Mean arterial pressure } \\
(\mathrm{MAP}) \text { and heart rate } \\
(\mathrm{HR})\end{array}$ & $\begin{array}{c}\text { The maternal separation stress model, MatSep, } \\
\text { sensitizes chronic blood pressure responses to } \\
\text { angiotensin II in renal phenotype in male but } \\
\text { not female rats }\end{array}$ \\
\hline \multicolumn{4}{|c|}{ 4. O'Sullivan et al., 2015} \\
\hline $\begin{array}{l}\quad n=64 \\
\text { Pregnant mice }\end{array}$ & $\begin{array}{l}\text { Prenatal corticosterone } \\
\qquad \begin{array}{l}\text { (CORT) } n=32 \\
\text { Control } n=32\end{array}\end{array}$ & $\begin{array}{c}\text { - Blood pressure } \\
\text { - Renal gene expression } \\
\text { - Nephron endowment } \\
\text { - Responses to increased } \\
\text { dietary sodium }\end{array}$ & $\begin{array}{l}\text { Prenatal CORT exposure reduced nephron } \\
\text { endowment and caused albuminuria in male } \\
\text { and female offspring; however, CORT-exposed } \\
\text { male offspring were hypotensive in a } \\
\text { salt-loading challenge, indicating that renal } \\
\text { changes (that are normally associated with } \\
\text { increased blood pressure) were being } \\
\text { overridden by other factors }\end{array}$ \\
\hline
\end{tabular}

5. Loria et al., 2017

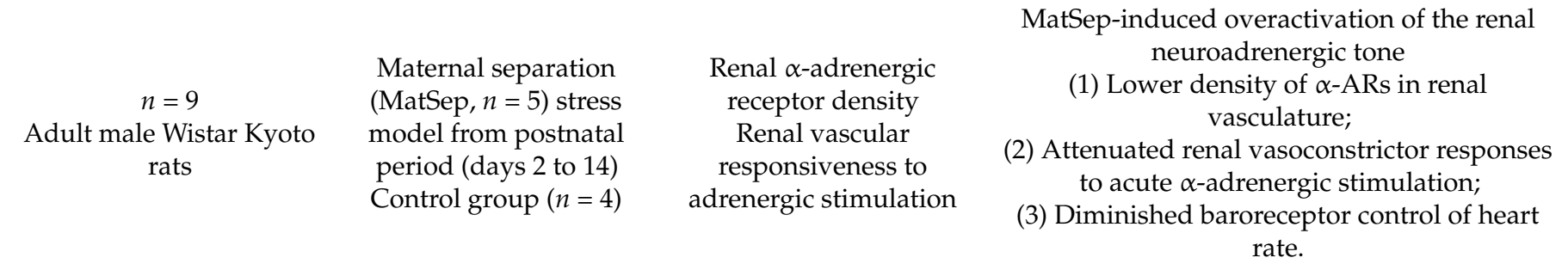

6. Marchon et al., 2018

$$
n=76
$$

Wistar rats

Prepubertal (4 weeks old) $n=40$

Adult rats (10 weeks old)

$$
n=36
$$

Immobilization
Renal morphological alterations
Irreversible glomerular loss

Renal impairment was interrupted by removal of the stress stimuli

\section{De Miguel et al., 2018}

$n=4-9 /$ group

Wistar Kyoto rats

Adult male (12 weeks old)
Maternal separation (MatSep)
Renal inflammatory state
"Priming" or sensitization of the immune system, resulting in an exaggerated gene expression response to an immune challenge in adulthood

Early-life stress-model-mediated sensitization of the immune system may play an important role in promoting cardiovascular disease earlier and more robustly in adulthood 
Table 2. Cont.

\begin{tabular}{|c|c|c|c|}
\hline \multicolumn{4}{|c|}{ Epidemiological Studies } \\
\hline Population & Exposure & Outcome & Key Findings \\
\hline \multicolumn{4}{|c|}{ 8. Poplawski et al., 2020} \\
\hline $\begin{array}{c}n=23 \\
\text { C57BL } / 6 \text { Mus } \\
\text { musculus mice, } \\
\text { adult male } \\
\text { stress animals } n=14 \text {, } \\
\text { control } n=9\end{array}$ & $\begin{array}{l}\text { Early-life transportation } \\
\text { stress model was } \\
\text { applied in mothers and } \\
\text { their pups }\end{array}$ & $\begin{array}{l}\text { Cardiorenal } \\
\text { metabolism }\end{array}$ & $\begin{array}{l}\text { Altered (i) organ weights, (ii) affective state, and } \\
\text { (iii) metabolites and/or metabolic pathways linked } \\
\text { to adverse mental health outcomes and metabolic } \\
\text { illness, such as cardiorenal syndrome, insulin } \\
\text { resistance, diabetes, and obesity } \\
\text { Stress-associated metabolic signatures in somatic } \\
\text { organs may provide early predictors of health } \\
\text { risks in later life and reveal new candidates for } \\
\text { peripheral biomarker detection with diagnostic } \\
\text { value }\end{array}$ \\
\hline
\end{tabular}

\subsection{Psychosocial Stressors}

The included epidemiological studies used a variety of methodologies to define and assess psychosocial stress as different explanatory variables: global perceived stress [33], low socioeconomic status [19,20,22,23], perceived discrimination [28], four constructs of psychological stress [24], psychosocial well-being [3], dispositional optimism [27], goalstriving stress [26], and clinical diagnosis of stress-related disorders [25]. The authors describe the use of self-administered questionnaires, including specific questions within a validated tool (e.g., Psychosocial Well-being Index short-form [3], 6-item Life Orientation Test-Revised scale LOT-R, INTERHEAR's psychological stress scale, list of threatening experience-LTE, Patient Health Questionnaire-PHQ 9, 9-item Discrimination Scale of the Experience of Discrimination questionnaire, Socioeconomic Status) [3,19-22,24,27,28].

The experimental studies included rodent (rat and mouse) species. Researchers used behavioral stress models where the pups were exposed to early-life stress (mainly postnatal period) by immobilization [31,32], maternal separation (MatSep) [29,36], glucocorticoids infusion [34,35] and transportation protocols [36].

\subsection{Kidney Outcomes}

Kidney function among population-based studies included baseline and repeated measures of serum/plasma creatinine and urinary albumin. The primary outcomes were the prevalence or incidence of CKD and CKD progression assessed through the estimated glomerular filtration rate (eGFR) decline [3,26,27]. GFR was estimated for using either the "Modification of Diet in Renal Disease (MDRD) Study" [19,20,22] or the Chronic Kidney Disease Epidemiology Collaboration equation models [3,24-27,37].

In animal studies, a variety of post-mortem renal histopathology analyses (estimation of the total number of glomeruli per kidney by stereological counting $[31,32,34,35]$ and $\alpha$-adrenergic receptors $\alpha$-ARs), plasmatic and urinary creatinine samples [37], renal inflammatory and metabolic biomarkers $[30,36]$ were carried out in exposed and control groups to examine stress-induced effects. Prenatal exposure to glucocorticoids resulted in postnatal growth restriction [34], with significant reduction in the kidney weight and total nephron number, increased mean arterial pressure, presence of albuminuria, and the expression of receptors in the renin-angiotensin system and apoptotic gene markers in offspring [34,35].

The experimental studies in postnatal exposure (prepuberal age) to physical immobilization, maternal separation, or transportation stress models showed significantly lower values of kidney weight, and glomerular volume density in the stressed group [31,32], as well as sensitization to arterial hypertension after angiotensin II infusion [33], exaggerated gene expression immune response (IL-1 $\beta$ and T cells) [36], reduced alfa-adrenergic receptor $(\alpha-\mathrm{AR})$ density in renal vasculature [29], and cardiorenal metabolic alterations [30]. 


\section{Discussion}

The literature search for this review focused on exposure to psychosocial stress and kidney function, and consistent with prior reviews $[8,25]$, we note that a growing body of evidence supports a link between lifetime stressors and CKD risk or kidney function decline. However, we note that there is an important gap in research for studies that examined earlylife or prenatal stress. Only two animal studies and one epidemiological study indirectly addressed this research question [33,36,38]. Specifically, we found no studies addressing psychosocial determinants of kidney health in early childhood, an area that remains a critical research need [39]. We included studies that reported associations between different psychosocial stressors (low socio-economic status, racial discrimination, migration, etc.) and poorer kidney health outcomes in previously healthy adult populations.

Individuals can be exposed to psychosocial stressors through different pathways, including poverty, low socioeconomic status, life events, pregnancy-related stressors, racial discrimination, and the presence of stress factors related to living conditions and the geographic area. These psychosocial stress factors have previously been associated with adverse perinatal effects that include low birth weight, small for gestational age, prematurity, neurodevelopment, metabolic, cardiovascular, and respiratory alterations $[6,7,40-43]$. Additionally, it is essential to acknowledge that exposure to chemical substances may have a synergistic effect in perinatal outcomes when pregnant women are co-exposed to psychosocial stressors and other environmental toxicants, both individually and at a community level [44-46]. As is the case for preterm birth, wherein concomitant exposure to adverse life events (e.g., poverty, racism, inequitable access to healthcare) as well as an individual's exposure to environmental toxicants (e.g., air pollution, metals, some pesticides, or phthalates), may also damage developing kidneys, reducing nephron endowment over the life course $[38,47,48]$. Co-exposures, or studies where psychosocial stress may be the result of other life events such as starvation, were outside the scope of this review.

Different biological mechanisms that enhance disease and frailty in adulthood have been described to explain early-life exposure to biologic and psychosocial stressors [49]. Specifically, regarding kidney development, nephrogenesis culmination between gestational weeks 34 and 36, together with nephron maturation in the early postnatal period, are critical windows of susceptibility [9]. Several studies demonstrated that low birth weight $(<2500 \mathrm{~g})$, prematurity and delayed intrauterine growth are associated with CKD in adulthood, secondary to elevated blood pressure, microalbuminuria presence and reduced estimate glomerular filtration rate $[50,51]$, because low birth weight correlates linearly with nephron number in children and adults [12,52].

From a neuroendocrine and epigenetics perspective, there is evidence suggesting that fetal, placental and maternal factors, associated through the multiple-hit hypothesis, influence the development of antenatal distress and adverse offspring outcomes by different pathways $[12,53]$. An adverse environment induces the long-lasting hyper-reactivity of physiological survival systems: stress responses on the maternal and fetal hypothalamicpituitary-adrenal (HPA) axis [54-56], immune and inflammatory responses [57,58], and energy-conserving responses [59]. Particularly, exposure to maternal-fetal undernutrition or psychosocial stress for a certain organ can impair growth, resulting in a permanently reduced number of normally functioning units (e.g., nephrons, cardiomyocytes, pancreatic insulin-secreting B cells) [60]. At the same time, reduced functional capacity can limit the ability of the organ to adapt to an increased functional load imposed postnatally, and increase the risk for later life kidney disease, heart failure, and diabetes [61]. Specifically, current evidence shows that the developmental programming of chronic conditions, such as diabetes, cardiovascular disease, obesity, and depression, has a transgenerational effect $[11,62]$ through the excessive expression of the glucocorticoid-responsive transcription factor called nuclear-receptor related 1 protein (NURR1) with environmental stress interactions during early life [63].

Regarding the developmental programming field, human studies are limited due to challenges in the inherent temporal lag between an adverse event during pregnancy and 
the occurrence of an associated clinical phenotype. Therefore, animal models are critically important in exploring possible mechanisms for kidney development under controlled conditions and in discrete developmental periods [64]. The correct assessment of the timing of psychosocial stress exposure in pregnancy may be key to determining potential fetal programming effects [64], because in humans and species such as sheep, nephrogenesis is largely completed before birth, whereas in rodents, rabbits, and pigs, nephron formation and completion continue in the postnatal period $[65,66]$. Furthermore, many psychosocial stressors cannot be recreated or simulated in a laboratory setting.

The results of animal studies subject to different stress models report that prenatal and postnatal exposure to glucocorticoids is associated with: a reduced renal reserve $[31,32,34,35,67,68]$, changes in the vascular response to vasoconstrictors $[29,69]$, activity increase in the renin-angiotensin-aldosterone system and its renal and brain receptors [31,35], change in molecular pathways that regulate the kidney transcriptome [36,70], alterations of the immuno-inflammatory processes [71] and modifications in the baroreceptors response [29,35,72]; each of these factors jointly contributes to altered kidney development and the potentially increased risk of later life arterial hypertension and CKD $[34,53,73]$. Additionally, recent evidence suggests a transgenerational transmission of these alterations through epigenetic mechanisms such as chromatin remodeling and modifications of non-codifying RNA [11,52].

During pregnancy, psychosocial stressors may contribute to the persistence of disparities of adverse birth outcomes across specific socioeconomic and ethnic groups. Higher levels of psychosocial stress may be associated with lower SES populations, where food insecurity, greater financial strain, and job strain are more prevalent compared to higher SES groups [74]. Perceived stress and depression may also be higher among non-white women as a result of racial discrimination [28]. The Cumulative Disadvantage Theory highlights how early social and economic advantage or disadvantage shapes the health outcomes of socially defined groups over time [8]. However, Luneyra et al. concluded that life stressors were negatively associated with prevalent CKD at baseline in the Jackson Heart Study cohort. It is important to understand the underlying factors driving the unexplained disparities in CKD outcomes among African Americans; therefore, future studies should delineate the potential role of biological markers in the relationship between psychosocial factors and kidney health [33], while recognizing genetic factors associated with CKD in risk groups such as African Americans.

This review has some limitations. The search strategy used terms that included different psychosocial stress factors. However, it is not an exhaustive list that includes all possibilities and interactions with others biological, genetics, quality of healthcare systems, maternal comorbidities, family support, and environmental factors to address their cumulative effects in the nephron endowment. We only included studies published in English between 2007 and 2020, carried out in high-income countries. Due to the heterogeneity of articles identified, we could not find a definitive answer to our research question. We did not formally evaluate the level of evidence of the studies because this was not the main goal of our scoping review. It is also important to highlight that some of the epidemiological evidence arose from a single cohort study (the Jackson Heart Study), although applied different metrics for the evaluation of psychosocial stressors. Our findings provide a guide for future prospective epidemiological studies or controlled experimental trials that interrogate the causal roles of psychosocial early-life stress and kidney function, considering the timing of outcome and exposure in the critical windows of susceptibility, and other risk factors such as the dehydration and sex effects $[3,12,25]$.

Finally, findings between studies can also vary considerably depending on the methodological approaches to measuring psychosocial stress. Self-report questionnaires may be biased due to either over- or under-reporting. By measuring clinical parameters, e.g., cortisol levels, blood pressure or heart rate, it is possible to better evaluate the response to stress $[75,76]$, although not always feasible. 


\section{Conclusions}

Epidemiological evidence in adult populations shows the association of different psychosocial stressors on kidney function, and the overall evidence in animal studies is consistent with the independent effects of prenatal psychosocial stress on perinatal and postnatal outcomes. We conclude that there is an important gap to fill with human studies between exposure to psychosocial stress during pregnancy and kidney outcomes.

Author Contributions: Conceptualization, A.P.S. and M.T.-O.; methodology, J.A.E.-G., M.T.-O.; formal analysis, J.A.E.-G.; data curation, J.A.E.-G.; writing-original draft preparation, J.A.E.-G., A.P.S. and M.T.-O.; writing-review and editing, A.P.S. and M.T.-O.; supervision, A.P.S. and M.T.-O. All authors have read and agreed to the published version of the manuscript.

Funding: This research received no external funding.

Institutional Review Board Statement: Not applicable.

Informed Consent Statement: Not applicable.

Data Availability Statement: Not applicable.

Conflicts of Interest: The authors declare no conflict of interest.

\section{References}

1. Bikbov, B.; Purcell, C.A.; Levey, A.S.; Smith, M.; Abdoli, A.; Abebe, M.; Adebayo, O.M.; Afarideh, M.; Agarwal, S.K.; AgudeloBotero, M.; et al. Global, Regional, and National Burden of Chronic Kidney Disease, 1990-2017: A Systematic Analysis for the Global Burden of Disease Study 2017. Lancet 2020, 395, 709-733. [CrossRef]

2. George, C.; Mogueo, A.; Okpechi, I.; Echouffo-Tcheugui, J.B.; Kengne, A.P. Chronic Kidney Disease in Low-Income to MiddleIncome Countries: The Case f Increased Screening. BMJ Glob. Health 2017, 2, e000256. [CrossRef]

3. Kim, J.Y.; Joo, Y.S.; Jhee, J.H.; Han, S.H.; Yoo, T.-H.; Kang, S.-W.; Park, J.T. Effect of Psychosocial Distress on the Rate of Kidney Function Decline. J. Gen. Intern. Med. 2021. [CrossRef]

4. Hamer, M.; Chida, Y.; Molloy, G.J. Psychological Distress and Cancer Mortality. J. Psychosom. Res. 2009, 66, 255-258. [CrossRef] [PubMed]

5. Robinson, K.L.; McBeth, J.; MacFarlane, G.J. Psychological Distress and Premature Mortality in the General Population: A Prospective Study. Ann. Epidemiol. 2004, 14, 467-472. [CrossRef]

6. Hobel, C.J.; Goldstein, A.; Barrett, E.S. Psychosocial Stress and Pregnancy Outcome. Clin. Obstet. Gynecol. 2008, 51, 333-348. [CrossRef] [PubMed]

7. Littleton, H.L.; Bye, K.; Buck, K.; Amacker, A. Psychosocial Stress during Pregnancy and Perinatal Outcomes: A Meta-Analytic Review. J. Psychosom. Obstet. Gynecol. 2010, 31, 219-228. [CrossRef]

8. Bruce, M.A.; Griffith, D.M.; Thorpe, R.J. Stress and the Kidney. Adv. Chronic Kidney Dis. 2015, 22, 46-53. [CrossRef] [PubMed]

9. Bruce, M.A.; Beech, B.M.; Sims, M.; Brown, T.N.; Wyatt, S.B.; Taylor, H.A.; Williams, D.R.; Crook, E. Social environmental stressors, psychological factors, and kidney disease. J. Investig. Med. 2009, 57, 583-589. [CrossRef]

10. Barker, D.J.P. The Origins of the Developmental Origins Theory. J. Intern. Med. 2007, 261, 412-417. [CrossRef] [PubMed]

11. Briffa, J.F.; Wlodek, M.E.; Moritz, K.M. Transgenerational Programming of Nephron Deficits and Hypertension. Semin. Cell Dev. Biol. 2020, 103, 94-103. [CrossRef]

12. Luyckx, V.A.; Brenner, B.M. Clinical Consequences of Developmental Programming of Low Nephron Number. Anat. Rec. 2020, 303, 2613-2631. [CrossRef] [PubMed]

13. Schreuder, M.F. Safety in glomerular numbers. Pediatr. Nephrol. 2012, 27, 1881-1887. [CrossRef]

14. Moritz, K.M.; Singh, R.R.; Probyn, M.E.; Denton, K.M. Developmental programming of a reduced nephron endowment: More than just a baby's birth weight. Am. J. Physiol. Physiol. 2009, 296, F1-F9. [CrossRef]

15. Arksey, H.; O'Malley, L. Scoping Studies: Towards a Methodological Framework. Int. J. Soc. Res. Methodol. Theory Pract. 2005, 8, 19-32. [CrossRef]

16. Tricco, A.C.; Lillie, E.; Zarin, W.; O’Brien, K.K.; Colquhoun, H.; Levac, D.; Moher, D.; Peters, M.D.J.; Horsley, T.; Weeks, L.; et al. PRISMA extension for scoping reviews (PRISMA-ScR): Checklist and explanation. Ann. Intern. Med. 2018, 169, 467-473. [CrossRef]

17. VandenBos, G.R. APA Dictionary of Psychology; American Psychological Association: Washington, DC, USA, 2007; ISBN 978-159147-380-0.

18. American Psychiatric Association, A. Diagnostic and Statistical Manual of Mental Disorders; American Psychiatric Association: Washington, DC, USA, 2000; Volume 4.

19. Crews, D.C.; Charles, R.F.; Evans, M.K.; Zonderman, A.B.; Powe, N.R. Poverty, Race, and CKD in a Racially and Socioeconomically Diverse Urban Population. Am. J. Kidney Dis. 2010, 55, 992-1000. [CrossRef] [PubMed] 
20. Shoham, D.A.; Vupputuri, S.; Diez Roux, A.; Kaufman, J.S.; Coresh, J.; Kshirsagar, A.; Zeng, D.; Heiss, G. Kidney Disease in Life-Course Socioeconomic Context: The Atherosclerosis Risk in Communities (ARIC) Study. Am. J. Kidney Dis. 2007, 49, 217-226. [CrossRef] [PubMed]

21. Lunyera, J.; Davenport, C.A.; Bhavsar, N.A.; Sims, M.; Scialla, J.; Pendergast, J.; Hall, R.; Tyson, C.C.; Clair Russell, J.; Wang, W.; et al. Nondepressive Psychosocial Factors and CKD Outcomes in Black Americans. Clin. J. Am. Soc. Nephrol. 2018, 13, 213-222. [CrossRef]

22. Bruce, M.A.; Beech, B.M.; Crook, E.D.; Sims, M.; Wyatt, S.B.; Flessner, M.F.; Taylor, H.A.; Williams, D.R.; Akylbekova, E.L.; Ikizler, T.A. Association of Socioeconomic Status and CKD Among African Americans: The Jackson Heart Study. Am. J. Kidney Dis. 2010, 55, 1001-1008. [CrossRef] [PubMed]

23. Lunyera, J.; Stanifer, J.W.; Davenport, C.A.; Mohottige, D.; Bhavsar, N.A.; Scialla, J.J.; Pendergast, J.; Boulware, L.E.; Diamantidis, C.J. Life Course Socioeconomic Status, Allostatic Load, and Kidney Health in Black Americans. Clin. J. Am. Soc. Nephrol. 2020, 15, 341-348. [CrossRef] [PubMed]

24. Adjei, D.N.; Stronks, K.; Adu, D.; Beune, E.; Meeks, K.; Smeeth, L.; Addo, J.; Owusu-Dabo, E.; Klipstein-Grobusch, K.; Mockenhaupt, F; et al. Cross-Sectional Study of Association between Psychosocial Stressors with Chronic Kidney Disease among Migrant and Non-Migrant Ghanaians Living in Europe and Ghana: The RODAM Study. BMJ Open 2019, 9. [CrossRef] [PubMed]

25. Su, G.; Song, H.; Lanka, V.; Liu, X.; Fang, F.; Valdimarsdóttir, U.A.; Carrero, J.J. Stress Related Disorders and the Risk of Kidney Disease. Kidney Int. Rep. 2021, 6, 706-715. [CrossRef]

26. Cain-Shields, L.; Glover, L.; Young, B.; Sims, M. Association between Goal-Striving Stress and Rapid Kidney Function Decline among African Americans: The Jackson Heart Study. J. Investig. Med. 2021, 69, 382-387. [CrossRef]

27. Glover, L.M.; Butler-Williams, C.; Cain-Shields, L.; Forde, A.T.; Purnell, T.S.; Young, B.; Sims, M. Optimism Is Associated with Chronic Kidney Disease and Rapid Kidney Function Decline among African Americans in the Jackson Heart Study. J. Psychosom. Res. 2020, 139, 110267. [CrossRef]

28. Beydoun, M.A.; Poggi-Burke, A.; Zonderman, A.B.; Rostant, O.S.; Evans, M.K.; Crews, D.C. Perceived Discrimination and Longitudinal Change in Kidney Function among Urban Adults. Psychosom. Med. 2017, 79, 824-834. [CrossRef]

29. Loria, A.S.; Osborn, J.L. Maternal Separation Diminishes $\alpha$-Adrenergic Receptor Density and Function in Renal Vasculature from Male Wistar-Kyoto Rats. Am. J. Physiol. Ren. Physiol. 2017, 313, F47-F54. [CrossRef]

30. Poplawski, J.; Radmilovic, A.; Montina, T.D.; Metz, G.A.S. Cardiorenal Metabolic Biomarkers Link Early Life Stress to Risk of Non-Communicable Diseases and Adverse Mental Health Outcomes. Sci. Rep. 2020, 10. [CrossRef]

31. Benchimol De Souza, D.; Silva, D.; Marinho Costa Silva, C.; Barcellos Sampaio, F.J.; Silva Costa, W.; Martins Cortez, C. Effects of Immobilization Stress on Kidneys of Wistar Male Rats: A Morphometrical and Stereological Analysis. Kidney Blood Press. Res. 2011, 34, 424-429. [CrossRef]

32. Marchon, R.G.; Ribeiro, C.T.; Costa, W.S.; Sampaio, F.J.B.; Pereira-Sampaio, M.A.; Souza, D.B. Immediate and Late Effects of Stress on Kidneys of Prepubertal and Adult Rats. Kidney Blood Press. Res. 2018, 43, 1919-1926. [CrossRef]

33. Loria, A.S.; Brands, M.W.; Pollock, D.M.; Pollock, J.S. Early Life Stress Sensitizes the Renal and Systemic Sympathetic System in Rats. Am. J. Physiol. Ren. Physiol. 2013, 305. [CrossRef]

34. O'Sullivan, L.; Cuffe, J.S.M.; Koning, A.; Singh, R.R.; Paravicini, T.M.; Moritz, K.M. Excess Prenatal Corticosterone Exposure Results in Albuminuria, Sex-Specific Hypotension, and Altered Heart Rate Responses to Restraint Stress in Aged Adult Mice. Am. J. Physiol. Ren. Physiol. 2015, 308, F1065-F1073. [CrossRef] [PubMed]

35. Singh, R.R.; Cullen-McEwen, L.A.; Kett, M.M.; Boon, W.M.; Dowling, J.; Bertram, J.F.; Moritz, K.M. Prenatal Corticosterone Exposure Results in Altered AT1/AT2, Nephron Deficit and Hypertension in the Rat Offspring. J. Physiol. 2007, 579, 503-513. [CrossRef]

36. Miguel, C.; Obi, I.E.; Ho, D.H.; Loria, A.S.; Pollock, J.S. Early Life Stress Induces Immune Priming in Kidneys of Adult Male Rats. Am. J. Physiol. Ren. Physiol. 2018, 314, F343-F355. [CrossRef]

37. Loria, A.S.; Yamamoto, T.; Pollock, D.M.; Pollock, J.S. Early Life Stress Induces Renal Dysfunction in Adult Male Rats but Not Female Rats. Am. J. Physiol. Regul. Integr. Comp. Physiol. 2013, 304, R121-R129. [CrossRef]

38. Brophy, P.D.; Shoham, D.A.; Charlton, J.R.; Carmody, J.B.; Reidy, K.J.; Harshman, L.; Segar, J.; Askenazi, D. Early-Life Course Socioeconomic Factors and Chronic Kidney Disease. Adv. Chronic Kidney Dis. 2015, 22, 16-23. [CrossRef] [PubMed]

39. Brophy, P.D.; Charlton, J.R.; Bryan Carmody, J.; Reidy, K.J.; Harshman, L.; Segar, J.; Askenazi, D.; Shoham, D.; Bagby PD Brophy, S.P.; Charlton, J.; et al. Handbook of Life Course Health Development; Springer: Cham, Switzerland, 2018. [CrossRef]

40. Rosa, M.J.; Lee, A.G.; Wright, R.J. Evidence Establishing a Link between Prenatal and Early-Life Stress and Asthma Development. Curr. Opin. Allergy Clin. Immunol. 2018, 18, 148-158. [CrossRef] [PubMed]

41. Rosa, M.J.; Just, A.C.; Tamayo y Ortiz, M.; Schnaas, L.; Svensson, K.; Wright, R.O.; Téllez Rojo, M.M.; Wright, R.J. Prenatal and Postnatal Stress and Wheeze in Mexican Children. Ann. Allergy Asthma Immunol. 2016, 116, 306-312.e1. [CrossRef] [PubMed]

42. Esparza-Aguilar, M.; Arroyo, P.; Gómez-Verján, J.C.; Martín-Martín, V. Early life exposure and its association with diseases in adulthood: Review of longitudinal studies. Bol. Med. Hosp. Infant. Mex. 2020, 77, 153-165. [CrossRef]

43. Wen, D.; Poh, J.; Ni, S.; Chong, Y.; Chen, H.; Kwek, K.; Shek, L.; Gluckman, P.; Fortier, M.; Meaney, M.; et al. Influences of Prenatal and Postnatal Maternal Depression on Amygdala Volume and Microstructure in Young Children. Transl. Psychiatry 2017, 7. [CrossRef] 
44. Padula, A.M.; Monk, C.; Brennan, P.A.; Borders, A.; Barrett, E.S.; McEvoy, C.T.; Foss, S.; Desai, P.; Alshawabkeh, A.; Wurth, R.; et al. A Review of Maternal Prenatal Exposures to Environmental Chemicals and Psychosocial Stressors-Implications for Research on Perinatal Outcomes in the ECHO Program. J. Perinatol. 2019, 40, 10-24. [CrossRef]

45. Padula, A.M.; Rivera-Núñez, Z.; Barrett, E.S. Combined Impacts of Prenatal Environmental Exposures and Psychosocial Stress on Offspring Health: Air Pollution and Metals. Curr. Environ. Health Rep. 2020, 7, 89-100. [CrossRef] [PubMed]

46. Jacobson, M.H.; Wu, Y.; Liu, M.; Attina, T.M.; Naidu, M.; Karthikraj, R.; Kannan, K.; Warady, B.A.; Furth, S.; Vento, S.; et al. Serially Assessed Bisphenol A and Phthalate Exposure and Association with Kidney Function in Children with Chronic Kidney Disease in the US and Canada: A Longitudinal Cohort Study. PLoS Med. 2020, 17, e1003384. [CrossRef] [PubMed]

47. Brophy, P.D.; Charlton, J.R.; Bryan Carmody, J.; Reidy, K.J.; Harshman, L.; Segar, J.; Askenazi, D.; Shoham, D.; Bagby, S.P. Chronic Kidney Disease: A Life Course Health Development Perspective. In Handbook of Life Course Health Development; Halfon, N., Forrest, C.B., Lerner, R.M., Faustman, E.M., Eds.; Springer International Publishing: Berlin, Germany, 2018; pp. 375-401. ISBN 978-3-319-47143-3.

48. Ferguson, K.K.; Chin, H.B. Environmental Chemicals and Preterm Birth: Biological Mechanisms and the State of the Science. Curr. Epidemiol. Rep. 2017, 4, 56-71. [CrossRef]

49. Pérez-Zepeda, M.U.; Ávila-Funes, J.A.; Gutiérrez-Robledo, L.M.; García-Peña, C. Frailty Across Age Groups. J. Frailty Aging 2016, 5, 15-19. [CrossRef]

50. Das, S.K.; Mannan, M.; Faruque, A.S.G.; Ahmed, T.; McIntyre, H.D.; Mamun, A. Effect of Birth Weight on Adulthood Renal Function: A Bias-Adjusted Meta-Analytic Approach. Nephrology 2016, 21, 547-565. [CrossRef]

51. Nüsken, E.; Voggel, J.; Fink, G.; Dötsch, J.; Nüsken, K.-D. Impact of Early-Life Diet on Long-Term Renal Health. Mol. Cell. Pediatrics 2020, 7. [CrossRef] [PubMed]

52. Luyckx, V.A. Preterm Birth and Its Impact on Renal Health. Semin. Nephrol. 2017, 37, 311-319. [CrossRef]

53. Voggel, J.; Mohr, J.; Nüsken, K.D.; Dötsch, J.; Nüsken, E.; Alejandre Alcazar, M.A. Translational Insights into Mechanisms and Preventive Strategies after Renal Injury in Neonates. Semin. Fetal Neonatal Med. 2021, 101245. [CrossRef]

54. Cunliffe, V.T. The epigenetic impacts of social stress: How does social adversity become biologically embedded? Epigenomics 2016, 8, 1653-1669. [CrossRef]

55. Glover, V.; O'Connor, T.G.; O'Donnell, K. Prenatal stress and the programming of the HPA axis. Neurosci. Biobehav. Rev. 2010, 35, 17-22. [CrossRef]

56. Meyer, J.S. Biochemical effects of corticosteroids on neural tissues. Physiol. Rev. 1985, 65, 946-1020. [CrossRef]

57. Chen, T.; Liu, H.X.; Yan, H.Y.; Wu, D.M.; Ping, J. Developmental Origins of Inflammatory and Immune Diseases. Mol. Hum. Reprod. 2016, 22, 558-565. [CrossRef]

58. Coussons-Read, M.E.; Okun, M.L.; Nettles, C.D. Psychosocial Stress Increases Inflammatory Markers and Alters Cytokine Production across Pregnancy. Brain Behav. Immun. 2007, 21, 343-350. [CrossRef]

59. Hales, C.N.; Barker, D.J.P. The Thrifty Phenotype Hypothesis. Br. Med. Bull. 2001, 60, 5-20. [CrossRef] [PubMed]

60. Hanson, M.A.; Gluckman, P.D. Early developmental conditioning of later health and disease: Physiology or pathophysiology? Physiol. Rev. 2014, 94, 1027-1076. [CrossRef]

61. Bagby, S.P. Prenatal origins of chronic kidney disease. In Chronic Renal Disease; Elsevier: Amsterdam, The Netherlands, 2015; pp. 783-799.

62. Babenko, O.; Kovalchuk, I.; Metz, G.A. Stress-Induced Perinatal and Transgenerational Epigenetic Programming of Brain Development and Mental Health. Neurosci. Biobehav. Rev. 2015, 48, 70-91. [CrossRef]

63. Bordoni, L.; Petracci, I.; Calleja-Agius, J.; Lalor, J.G.; Gabbianelli, R. NURR1 Alterations in Perinatal Stress: A First Step towards Late-Onset Diseases? A Narrative Review. Biomedicines 2020, 8, 584. [CrossRef] [PubMed]

64. Dorey, E.S.; Pantaleon, M.; Weir, K.A.; Moritz, K.M. Adverse prenatal environment and kidney development: Implications for programing of adult disease. Reproduction 2014, 147, R189-R198. [CrossRef]

65. Moritz, K.M. The Effect of the In utero Environment on Nephrogenesis and Renal Function. In Kidney Development, Disease, Repair and Regeneration; Elsevier: Amsterdam, The Netherlands, 2016; pp. 177-190.

66. Seely, J.C. A Brief Review of Kidney Development, Maturation, Developmental Abnormalities, and Drug Toxicity: Juvenile Animal Relevancy. J. Toxicol. Pathol. 2017, 30, 125-133. [CrossRef] [PubMed]

67. Ortiz, L.A.; Quan, A.; Weinberg, A.; Baum, M. Effect of Prenatal Dexamethasone on Rat Renal Development. Kidney Int. 2001, 59, 1663-1669. [CrossRef]

68. Jain, J.; Legan, S.K.; Alhamoud, I.; Gattineni, J.; Baum, M. Effect of Sex on Glomerular Filtration Rate in Programmed Rats by Prenatal Dexamethasone. Physiol. Rep. 2019, 7. [CrossRef] [PubMed]

69. Molnar, J.; Howe, D.C.; Nijland, M.J.M.; Nathanielz, P.W. Prenatal dexamethasone leads to both endothelial dysfunction and vasodilatory compensation in sheep. J. Physiol. 2003, 547, 61-66. [CrossRef] [PubMed]

70. Dressler, G.R.; Patel, S.R. Epigenetics in Kidney Development and Renal Disease. Transl. Res. 2015, 165, 166-176. [CrossRef]

71. Pedersen, J.M.; Mortensen, E.L.; Christensen, D.S.; Rozing, M.; Brunsgaard, H.; Meincke, R.H.; Petersen, G.L.; Lund, R. Prenatal and Early Postnatal Stress and Later Life Inflammation. Psychoneuroendocrinology 2018, 88, 158-166. [CrossRef]

72. Forhead, A.J.; Jellyman, J.K.; Blasio, M.J.; Johnson, E.; Giussani, D.A.; Pipkin, F.B.; Fowden, A.L. Maternal Dexamethasone Treatment Alters Tissue and Circulating Components of the Renin-Angiotensin System in the Pregnant Ewe and Fetus. Endocrinology 2015, 156, 3038-3046. [CrossRef] 
73. Luyckx, V.A.; Bertram, J.F.; Brenner, B.M.; Fall, C.; Hoy, W.E.; Ozanne, S.E.; Vikse, B.E. Effect of Fetal and Child Health on Kidney Development and Long-Term Risk of Hypertension and Kidney Disease. Lancet 2013, 382, 273-283. [CrossRef]

74. Bécares, L.; Atatoa-Carr, P. The Association between Maternal and Partner Experienced Racial Discrimination and Prenatal Perceived Stress, Prenatal and Postnatal Depression: Findings from the Growing up in New Zealand Cohort Study. Int. J. Equity Health 2016, 15, 1-12. [CrossRef]

75. DiPietro, J.A. Maternal Stress in Pregnancy: Considerations for Fetal Development. J. Adolesc. Health 2012, 51, S3-S8. [CrossRef] [PubMed]

76. DiPietro, J.A. The Role of Prenatal Maternal Stress in Child Development. Curr. Dir. Psychol. Sci. 2004, 13, 71-74. [CrossRef] 